\title{
Effects of acupuncture in adults with temporomandibular disorders*
}

\author{
Efeito da acupuntura em adultos com disfunção temporomandibular
}

\author{
Maria da Luz Rosario de Sousa ${ }^{1}$, Clotilde Shumiko Mashuda², Jorge Eiji Sato ${ }^{3}$, José Tadeu Tesseroli de Siqueira ${ }^{4}$ \\ ${ }^{*}$ Received from the Dentistry School of Piracicaba, State University of Campinas, Piracicaba, SP, Brazil.
}

DOI 10.5935/1806-0013.20140024

\section{ABSTRACT}

BACKGROUND AND OBJECTIVES: Temporomandibular disorders are functional and/or structural temporomandibular joint changes, of multifactorial origin, thus difficult to treat. So, acupuncture is a very useful alternative to handle such disorders. This study aimed at evaluating in adults with temporomandibular disorders, after at least 12 months of acupuncture treatment, whether results were maintained.

METHODS: Participated in the study 20 patients with temporomandibular disorders, treated in the acupuncture clinic of the Dentistry School of Piracicaba, State University of Campinas, who were evaluated in the beginning, immediately after treatment and at least 12 months after treatment, through the visual analog scale (VAS). Patients' history was obtained in the initial visit, according to Traditional Chinese Medicine patterns, being checked pain intensity reported by patients (VASO). Acupuncture was performed aiming at the energetic balance according to diagnosed pattern and reported pain (VAS1) was again evaluated at treatment completion (mean of six sessions lasting 20 minutes). Patients were revaluated (VAS2) after at least 12 months (12 to 18 months). ANOVA was used to compare moments initial, post-treatment and one year after, with significance of 5\%.

RESULTS: Means for VAS0, VAS1 and VAS2 were 5.9, 1.65 and 2.45, respectively. There has been statistical difference between VAS0 and VAS1 $(\mathrm{p}<0.01)$ and between VASO and VAS2 $(p<0.01)$, however not between VAS1 and VAS2 $(p>0.05)$.

CONCLUSION: Data have shown that acupuncture treatment in adults with temporomandibular disorders has decreased pain and that such decrease was maintained for at least 12 months.

Keywords: Acupuncture, Oral health, Orofacial pain, Temporomandibular joint.

1. School of Dentistry, Piracicaba, SP, Brazil.

2. Brazilian College of Acupuncture, São Paulo, SP, Brazil.

3. Brazilian Medical Association, Medical College of Acupuncture, São Paulo, SP, Brazil.

4. University of São Paulo, School of Medicine, São Paulo, SP, Brazil.

Submitted in August 15, 2013.

Accepted for publication in April 03, 2014.

Conflict of interests: none.

Correspondence to:

Maria da Luz Rosario de Sousa

Faculdade de Odontologia de Piracicaba

Avenida Limeira, 901 - Areiâo

13414-018 Piracicaba, SP, Brasil.

E-mail: luzsousa@fop.unicamp.br

( ) Sociedade Brasileira para o Estudo da Dor

\section{RESUMO}

JUSTIFICATIVA E OBJETIVOS: As disfunçôes temporomandibulares são alteraçóes funcionais e/ou estruturais das articulaçôes temporomandibulares, de origem multifatorial e, portanto de difícil tratamento. Sendo assim, a acupuntura apresenta-se como uma alternativa muito útil no manuseio dessas disfunçóes. O objetivo deste estudo foi avaliar em adultos com disfunçóes temporomandibulares, após no mínimo 12 meses do tratamento com acupuntura, se houve manutenção dos resultados.

MÉTODOS: Foram avaliados 20 pacientes com disfunçôes temporomandibulares, na clínica de acupuntura da Faculdade de Odontologia de Piracicaba da Universidade Estadual de Campinas, ao início, imediatamente após tratamento e após no mínimo 12 meses do tratamento com acupuntura, através da escala analógica visual (EAV). Na consulta inicial foi realizada uma anamnese segundo os padróes da Medicina Tradicional Chinesa sendo verificada a intensidade de dor relatada pelo paciente (EAV0). A acupuntura foi realizada buscando-se o equilíbrio energético de acordo com o padrão diagnosticado, sendo ao final do tratamento (em média seis sessóes de 20 minutos) avaliada novamente a dor relatada (EAV1). Após no mínimo 12 meses (12 a 18 meses) os pacientes foram reavaliados (EAV2). Utilizouse a ANOVA para comparação entre os momentos inicial, póstratamento e após um ano, com significância de 5\%.

RESULTADOS: As médias para EAV0, EAV1 e EAV2 foram 5,9, 1,65 e 2,45 respectivamente. Houve diferença estatística entre EAV0 e EAV1 $(\mathrm{p}<0,01)$, e entre EAV0 e EAV2 $(\mathrm{p}<0,01)$, porém não entre EAV1 e EAV2 ( $\mathrm{p}>0,05)$.

CONCLUSÁO: Os dados apontaram que o tratamento com acupuntura em adultos com disfunção temporomandibular reduziu a dor e que essa redução se manteve pelo menos por 12 meses.

Descritores: Acupuntura, Articulação temporomandibular, Dor orofacial, Saúde bucal.

\section{INTRODUCTION}

Temporomandibular disorders (TMD), set of joint and/or muscle disorders affecting the temporomandibular joint (TMJ), have multifactorial origin ${ }^{1}$. So, there is the need for an interdisciplinary approach, being reversible and noninvasive the most indicated therapies.

Conventional treatment of these disorders is in general based on recommendation of jaw exercises, local application of ice or heat, self-massage, trigger-points (TP) inactivation, use of anti- 
inflammatory drugs and neuromuscular blockers, in addition to occlusal splint, therapy which is traditionally indicated.

Acupuncture has been used in Dentistry for several conditions, such as xerostomy, bruxism and less use of drugs ${ }^{2}$, and appears as indication for TMD patients because it acts by stimulating opioids release by the body, acting on pain control, that is, by needle insertion on specific points (acupoints) there is central nervous system (CNS) and peripheral nervous system stimulation and neurotransmitters release, which favor restoration process. Stimulated nervous fibers induce CNS to produce neurotransmitters and neurohumoral substances which control pain, stress, anxiety and several other processes $^{3}$.

A scientific review study ${ }^{4}$ has identified 74 articles published on acupuncture in Dentistry, of which 14 specifically about TMD, being that six were evaluated for meeting established methodological inclusion criteria and all have shown favorable results of the use of acupuncture to treat TMD, leading authors to consider it an alternative to conventional treatment.

In Brazil, a literature review ${ }^{5}$ has also concluded that acupuncture was as effective to control orofacial pain as conventional therapies, especially for pain of muscular origin.

Acupuncture allows for interdisciplinarity, in addition to integrating individuals' self-perception, allowing the change of primary disease causes ${ }^{6}$. This approach broadens the indication of acupuncture to handle TMDs, because it is known that the context to which individuals belong plays a major role in the occurrence of such disorders ${ }^{1}$.

TMD signs and symptoms are present in $33.3 \%$ of people, with higher prevalence from 21 to 40 years of age ${ }^{7}$, and may even impair quality of life of affected people ${ }^{8}$, so the literature has several studies recommending acupuncture to TMD patients ${ }^{9-13}$; however, our study has evaluated not only the post-treatment effect but also at least 12 months after treatment completion, in muscle TMD patients.

\section{METHODS}

Participated in the study 20 TMD patients who had already been submitted to treatment with acupuncture in the acupuncture clinic of FOP/UNICAMP (School of Dentistry of Piracicaba, State University of Campinas). During treatment, data were recorded on patients' medical records, including values obtained with the pain visual analog scale (VAS), in the beginning and at the end of the treatment. Inclusion criteria were patients having their data adequately recorded, having finished the treatment, in addition to having updated telephone contact.

Treatment comprised an initial evaluation where history was obtained according to Traditional Chinese Medicine (TCM) patterns, that is, according to energetic imbalance presented by patients, imbalance which, in most cases, was related to liver and/or heart, and patient-reported pain intensity was evaluated (VAS0). Acupuncture was performed aiming at energetic balance according to diagnosed pattern, being that at the end of treatment (mean estimate of eight weekly sessions lasting 20 minutes) pain was again evaluated (VAS1).
After at least 12 months (12 to 18 moths) patients were revaluated (VAS2). This revaluation was carried out by means of telephone contact by a person who had not participated in the initial study stages, informing patients about the reason of the call with the following sentence: "Good morning/afternoon Mr/Mrs, I am from the School of Dentistry of Piracicaba and I am getting in touch with you to get information about your current health status, after the acupuncture treatment you made with us approximately " $n$ " months ago (by the time of telephone calls, the date of latest patients' visit was checked in their records). Everything ok, with you?" Then, patients were reminded about pain scale scores before asking how they were currently feeling:

- By that time, you were asked about the level of pain you were feeling and you had to classify your pain. This classification has a scale from zero to 10 , where zero means no pain and 10 the maximum possible pain.

- Now, which score from zero to 10 would you give to your current status?

- Were you happy with the results of the acupuncture treatment? - Have you looked for other treatment related to your face problem, or did you have to use drugs in this meantime after treatment completion? If yes, which?

- Would you like to go back to treatment?

ANOVA (for two criteria) was used considering unequal variances aiming at comparing pain scale results between initial moment (VAS0), post-treatment (VAS1) and one year after (VAS2) with significance of $5 \%$.

All patients assisted by the Acupuncture Clinic of FOP/UNICAMP have signed the Free and Informed Consent Term associated to the project of evaluation of results with the use of acupuncture in Dentistry, approved by the Ethics Committee, FOP/UNICAMP number 099/2008 for the period from 2008 to 2012 .

\section{RESULTS}

Patients' age has varied from 16 to 67 years, being mean age 44 years. There were 15 females (75\%) and 5 males (25\%). The number of acupuncture sessions has varied from 4 to 10 sessions by treatment, with mean of 6 sessions.

VAS data regarding each patient in the initial moment (VAS0), immediately after treatment (VAS 1) and longitudinal (VAS2) are shown in figure 1. Visually one may see the initial pain scale above the others.

Mean VAS0 was $5.9 \pm 3.40$ with variation amplitude from zero to 10 . Mean VAS1 was $1.65 \pm 2.06$ with variation amplitude from zero to 5. Mean VAS2 was $2.45 \pm 3.15$ with variation amplitude from zero to 10 . There has been statistical difference between VAS0 and VAS1 $(\mathrm{p}<0.01)$, and between VAS0 and VAS2 $(\mathrm{p}<0.01)$, however not between VAS1 and VAS2 $(\mathrm{p}>0.05)$.

For 10 patients, pain has ceased after acupuncture treatment $(V A S 1=0)$. For 9 patients there has been maintenance of absence of pain for at least 12 months. However in 3 patients, VAS0 was already absence of pain in the initial session.

Twenty-percent of patients have looked for a different treatment 


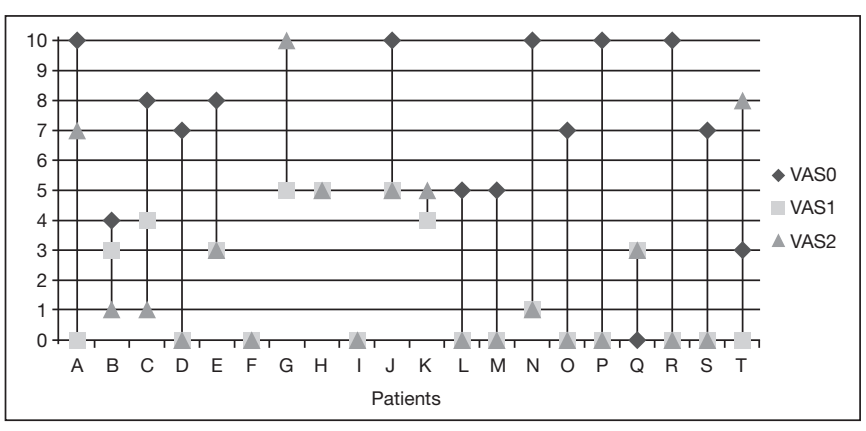

Figure 1. Distribution of temporomandibular disorder patients according to the visual analog scale before treatment (VASO), immediately after treatment (VAS1) and after at least one year (VAS2)

after acupuncture $(\mathrm{n}=4)$. From these, 2 have maintained VAS1 (zero for patient looking for treatment with occlusal splint and 3 for patient who replaced prostheses), one has increased (from 5 to 10, looked for neurologist) and one has decreased (from 3 to 1 , looked for occlusal splint).

From 16 patients answering the question whether they had been previously submitted to acupuncture, 11 had not been exposed to this treatment.

From 15 patients who were asked whether they would return to treatment, only 2 said no, one for believing that the pain he still had (VAS=5) was related to hypothyroidism and the other for being already asymptomatic (VAS2 $=0$ ). However others with VAS2 $=0(n=5)$ would return to treatment.

\section{DISCUSSION}

Both pain decrease (pain scale from 5.9 to 1.65 ) and maintenance of this decrease for at least one year after treatment (pain scale 2.45), were observed in this study, which has evaluated results of acupuncture treatment in adult patients with TMD, results which are similar to a different study ${ }^{11}$ where the initial pain scale was 7.35 with decrease after acupuncture treatment to 2.67, without, however, evaluating long term results.

Our study has evaluated chronic pain, that is, pain which is not characterized as an alert symptom for the occurrence of body injuries, being difficult to control and major cause of disability, being that TMD has major negative impact on the life of people, especially in the items psychological discomfort and disability ${ }^{8}$. So, acupuncture appears as a method indicated to treat TMDs, especially those of muscular origin ${ }^{5}$, such as the case of this study where pain decrease soon after treatment was $71 \%$ being that from those with pain in the initial evaluation, in $40 \%$ pain has totally disappeared after treatment $(\mathrm{VAS} 1=0)$.

Our patients were referred already diagnosed with muscle TMD by the occlusion clinic and by that time they had their diagnoses under the TCM vision, so treatment was individualized aiming at the energetic balance of the presented pattern. Other successful reports of TMD treatment with acupuncture are described in the literature, with the descriptions of such adopted treatment approaches $^{12-16}$.
In a study ${ }^{8}$, authors have shown the negative impact of oral health on the quality of life of individuals with TMD, a therapeutic problem to be also faced by dentists, being acupuncture one indication for therapeutic approach, where from patients who were submitted in average to 3.4 acupuncture sessions, $85 \%$ have benefited with pain intensity decrease of approximately $75 \%{ }^{11}$, which is very close to the value of our study.

Since pain is a frequent reason to look for the health system ${ }^{6}$, it is up to dentists from the health unit to be able to make the differential diagnosis and so choose the therapy, being acupuncture in public services a useful tool for health promotion actions. This association is very interesting considering the number of active individuals (patients with moderate to severe TMD signs and symptoms) or passive individuals (mild TMD signs), in addition to low acupuncture costs, also allowing an interdisciplinary approach by treating individuals as a whole, looking for their energetic balance.

Calls the attention the fact that $87 \%$ of such patients $(\mathrm{n}=13$ from 15 who answered) would like to return to treatment, even having obtained pain reduction and being happy with the treatment offered previously, being that 5 of them had no pain at the interview moment. This fact reinforces wellbeing and balance promoted by acupuncture.

So, acupuncture has shown to be an option to treat patients with chronic facial pain, especially those of muscular origin. Major acupuncture effect has been, since its early days, related to analgesia, using body's own analgesia mechanisms without causing side-effects. However, other effects are related to its action mechanism, such as anti-inflammatory and relaxing processes and increased immunity, in addition to decreasing anxiety and other psychological disorders.

Acupuncture action has been proven in dental procedures ${ }^{2,3}$ making them safer and cost-effective. Among most frequent acupuncture applications in Dentistry there are its application in the pre-assistance (patients with phobia to treatment, for example), during dentistic, endodontics periodontics and surgical procedures, to control TMD pain, bruxism and trismus, as well as in the postoperative period ${ }^{17}$. Other authors point to the contribution of acupuncture in cases of trigeminal neuralgia ${ }^{18}$. For TMD patients, focus of our study, the literature points that acupuncture is an excellent method additional to conventional approaches for cases of muscle involvement, especially those with difficulties to adapt to the occlusal splint ${ }^{5}$. In our study, these patients referred to the acupuncture clinic were in waiting list to install the occlusal splint and it was observed that only $2(10 \%)$ looked for this treatment in the long term after being submitted to acupuncture sessions. It is worth mentioning that $81 \%$ of these patients ( $\mathrm{n}=11$ from 16 answering this question) had never been submitted to acupuncture.

Experience with clinical cases treated with acupuncture has shown promising results, with pain scale decrease from $50 \%{ }^{16}$ to $80 \%{ }^{19}$, improvement in self-reported quality of life, in addition to significant improvement in dental acute pain, with 80 to $90 \%$ pain decrease $^{19}$.

Mean number of sessions per treatment in this study was below $(n=6)$ the initially planned mean $(n=8)$, probably because the 
treatment was able to balance patients' energetic imbalance for being individualized, thus specific for each pattern.

Notwithstanding this being a convenience sample, it was the universe of patients assisted between 2008 (year when the acupuncture clinic, FOP/UNICAMP was opened) and 2010, who have concluded their treatment and had all necessary data recorded in medical records. This group represents the profile of TMD patients looking for the service, who are mostly adults and females and may be pointing to a pattern of the Brazilian reality.

However, some limitations should be pointed out, such as possible bias of answers favoring acupuncture because patients knew that the telephone call was coming from FOP, fact which we tried to minimize by using an interviewer who had not participated in the previous stage and by the fact that in this stage patients could not see the scale. Complaints may have myalgic and/or arthralgic components, being pain primary or secondary. These situations have to be well differentiated for a good treatment prognosis. So, further studies evaluating acupuncture results should take these items into consideration in addition to diagnosis under TCM vision.

In Brazil, through the ordinance 971 from the Ministry of Health in 2006, there is the recommendation for the adoption and implementation of actions and services related to Integrative and Complementary Practices, considering acupuncture a health intervention technology integrally and dynamically addressing the health and disease process.

\section{CONCLUSION}

Data have shown that the treatment with acupuncture of adults with TMD has decreased pain and that this decrease was maintained for at least 12 months, thus indicating a field to be explored, especially in dentistry, adopting patients' holistic approach.

\section{REFERENCES}

1. Suvinen TI, Reade PC, Kemppainen P, Knonen M, Dworkin SF. Review of aetiological concepts of temporomandibular pain disorders: towards a biopsychosocial model for integration of physical disorder factors with psychological and psychosocial illness impact factors. Eur J Pain. 2005;9(6):613-33.

2. Vianna,RS, Souza AG, Silva BC, Berlinck TA, Dias KR. A acupuntura e sua aplicação na Odontologia. UFES Rev Odontol. 2008;10(4):48-52.

3. Rosted P. Introduction to acupuncture in dentistry. Br Dent J. 2000;189(3):136-40.

4. Rosted P. Practical recommendations for the use of acupuncture in the treatment of temporomandibular dysfunction based on the published controlled studies. Oral Dis. 2001;7(2):109-15.

5. Branco CA, Fonseca RB, Oliveira TR, Gomes VL, Fernandes Neto AJ. Acupuntura como tratamento complementar nas disfunçôes temporomandibulares: revisão da literatura. Rev Odontol UNESP. 2005;34(1):11-6.

6. Cintra ME, Figueiredo R. Acupuncture and health promotion: possibilities in public health services. Interface Comunic Saude Educ. 2010;14(32):139-54.

7. Mobilio N, Casetta I, Cesnik E, Catapano S. Prevalence of. self-reported symptoms related to temporomandibular disorders in an Italian population. J Oral Rehabil. 2011;38(12):884-90.

8. Dahlstrom L, Carlsson GE. Temporomandibular disorders and oral health-related quality of life. A systematic review. Acta Odontol Scand. 2010;68(2):80-5.

9. Smith P, Mosscrop D, Davies S, Sloan P, Al-Ani Zl. The efficacy of acupuncture in the treatment of temporomandibular joint myofascial pain: a randomised controlled trial. J. Dent. 2007;35( 3):259-67.

10. Wong Y, Cheng J. A case series of temporomandibular disorders treated with acupuncture, occlusal splint and point injection therapy. Acupuncture Med. 2003;21(4):13849.

11. Rosted P, Bundgaard M, Pedersen AM. The use of acupuncture in the treatment of temporomandibular dysfunction - an audit. Acupuncture Med. 2006;24(1):16-22.

12. Fortinguerra ML, Grillo CM, Meirelles MP, Sousa ML. Disfunção temporomandibular: acupuntura como tratamento alternativo. Relato de caso. Rev Paul Odontol. 2011;33(3):19-23.

13. Florian MR, Meirelles MP, Sousa ML. Disfunçẫo temporomandibular e acupuntura: uma terapia integrativa e complementar. Odontol Clin-Cient. 2011;10(2):189-92.

14. Zotelli VL, Meirelles MP, Sousa ML. Uso da acupuntura no manejo da dor em pacientes com alteraçóes na articulação temporomandibular (ATM). Rev Odontol Universidade Cidade de São Paulo. 2010;22(2):185-8.

15. Grillo CM, Meirelles MP, Sousa ML. Tratamento da disfunção temporomandibular com acupuntura. Relato de caso clínico. Rev Paul Odontol. 2010;32(1):31-3.

16. Meirelles MP, Gonçalo CS, Sousa ML. Manejo da dor orofacial através do tratamento com acupuntura: relato de um caso. Rev Odontol UNESP. 2009;38(6):379-82.

17. Nader HA Acupuntura na Odontologia - Um novo conceito. Revista da APCD 2003;57(1):49-51.

18. Grillo CM, Meirelles MP, Sousa ML. Controle da dor orofacial utilizando a técnica da acupuntura em uma paciente infantil com diagnóstico clínico de trigeminalgia. Rev ABO Nac. 2010;2011;(6):373-6.

19. Grillo CM, Wada RS, Sousa ML. Acupuntura e sangria no manejo da dor aguda de origem dentária. Rev Paul Odontol. 2011;33(2):33-8. 